\title{
A study on mediating role of organizational learning on relationship between market orientation and organizational performance
}

\author{
Azar Kafashpoor ${ }^{a}$, Mohammad Reza Hosseini Moghadam ${ }^{b^{*}}$, Masoud Monazzami Borhani ${ }^{\mathrm{c}}$ and Samira \\ Sabaghian $^{\text {d }}$
}

\author{
${ }^{a}$ Associate professor, Department of Business Management, Ferdowsi University of Mashhad, Mashhad, Iran \\ ${ }^{b}$ MA in Business Management, Ferdowsi University of Mashhad, Mashhad, Iran \\ ${ }^{c} B A$ in Business Management, Shandiz University of Mashhad, Mashhad, Iran \\ ${ }^{d}$ BA in Business Management, Binaloud University of Mashhad, Mashhad, Iran
}

\section{A R T I C L E I N F O}

\section{Article history:}

Received January 10, 2013

Received in Revised form

March, 26, 2013

Accepted 17 June 2013

Available online

18 June 2013

Keywords:

Organizational Learning

Market Orientation

Organizational Performance

\section{A B S T R A C T}

\begin{abstract}
Increasing intensity of competition among organizations in current century has caused everlasting search for ways to gain competitive advantage and win the competition. In this regard, organizational learning certainly counts as a competitive advantage to gain for today's managers. This study aims to discuss the mediating role of organizational learning in the relationship between market orientation and organizational performance. The study population includes all of the employees in the Central Office of Ferdowsi University of Mashhad. As 170 samples were randomly stratified and selected, information obtained was analyzed using SPSS software ver.20. While results support the significance of organizational learning's mediating role in the relationship between intelligence generation and intelligence dissemination with organizational performance, this role was declared insignificant in the relationship between responsiveness and organizational performance.
\end{abstract}

(C) 2012 Growing Science Ltd. All rights reserved.

\section{Introduction}

In view of the current global economics, Iran has changed into one of the fast-paced developing nations in the world. This Economy has witnessed an upsurge in competition by foreign companies and continued demand from overseas institutions to invest directly. Consequently, most Iranian firms are under pressure to prepare and develop their human resources based on international standards in skills, survival performance and retention. In this, organization learning presents a critical path for firms to function and gain competitive advantages, successfully. According to Akgün et al. (2003) anb Hoe and McShane (2010), organizational learning is a primary resource to improve organizational performance. For example, firms with the capacity to learn faster than competitors are

* Corresponding author

E-mail addresses: Mr.hoseyni2011@yahoo.com (MR Hosseini Moghadam) 
more likely to response more effectively to market challenges. More specifically, scholars have considered organizational learning as an essential factor in reaching competitive advantages. Strategic management (e.g., Dobni \& Luffman , 2003) and marketing (e.g., Jaworski \& Kohli , 1993) researchers posit that a market orientation (MO) provides firms with a source of competitive advantage (Kotlar, 2000; Kirca et al., 2005; Jiménez-Jimenez et al., 2008).

Organizational learning concept first appeared in 1970's. Organizational learning and market orientation are normally expected to measure customer values and responses of products and services offered and improve their performances. Relationships among organizational learning, market orientation and performance need be scrutinized as a part of a resource-based perspective (Barney, 1986). Therefore, we briefly discuss organizational learning, market orientation and organizational performance along with proposed assumptions, examine the conceptual model and finally present the results.

\section{Literature Review}

\subsection{Organizational Learning}

These days, the firms' learning activities were accepted to be realized via the employees working for them and firm either simplify or complicate these employees' learning activities and these firms contain "organizational learning system" within them (Daft \& Weick, 1984). Probst and Buchel (1997) described organizational learning as: "the ability of an organization, as a whole, to discover and correct the errors and to make a change in the knowledge and values of the organization in order to develop problem solving skills and capacity to create new jobs".

According to this definition, organizational learning features can be divided into a number of levels including individual, team and organizational. To explain the concept of learning in firms better, we must pay attention that learning is a dynamic significance and it is gradually altered from individual level to organizational. Due to the fact that organizational needs must adapt to environmental changes, this concept has obtained increasing attentions. Learning is not only necessary for the individual growth, but also it is essential for the firm, although, organizational learning is more than that of individuals combined. On other hand, organizational learning is widely discussed in literature across a myriad of fields, ranging from patient safety in health care and military readiness to library effectiveness, from information systems to student learning in school systems (Atwood \& Mora, 2010). Organizational learning theory parallels techniques of individual learning grounded in cognitive and social psychology and defines learning as organizational change. Researchers believe that a firm learns through the individual learning of its members (Pelham, 1997; Argyris \& Schön, 1978; Kim, 1993, b; Nevis et al., 1995; Schein, 1996; Simon, 1991; Agarwal, 2003).

However, organizational learning is an attempt to make sure that educational and training opportunities for employees fit with innovative goals (Dobni, 2008). Different studies disclose that organizational learning positively influences innovation and creativity in various business units (Calantone et al., 2002), since it supports them, leading to generation of new ideas and the ability to understand and to utilize them, appropriately.

The organizational learning process is characterized by a series of essential features. First, learning is a transformation process, which created and recreated, continuously and not an independent entity to be acquired or transmitted (Kolb, 1984). Second, it is cumulative, which means the amount of knowledge at a certain level in time is a function of the cumulated knowledge acquired until that moment. Finally, it is a process whose goal is to improve the development of the organization by means of new initiatives (technological, productive, or commercial) (Argyris \& Schön, 1978).

\subsection{Market orientation}

Market orientation can be described as a process of organizational development or as a reflection of organizational maturity (Kotler, 2000). Although the concept of market orientation was first introduced in $1950 \mathrm{~s}$, it has experienced substantial improvement in developing the concept since the 
80 s, where many analytical efforts have been made on its conceptualization and operationalization (Agrawal et al., 2003).

The market orientation (MO) concept, which has gained an outstanding position in the marketing literature, is still a research priority (Cano et al., 2004). Market orientation is an intelligence generation in terms of current and future customer demands across the organization and intelligence dissemination among various departments and respective responses (Kohli \& Jaworski, 1990). Market orientation is considered important in both outside and inside of the organization (Lings, 2004) and both domestic and international markets (Cadogan et al., 1995; Deshpande et al., 1993).

On the basis of their behavioral conceptualization, Kohli and Jaworski (1990) identified three main sub-dimensions of market orientation as follows,

1. Organization-wide generation of market intelligence relevant to current and future customer needs;

2. Cross departmental dissemination of the intelligence; and

\section{Responsiveness to market.}

There are literally various activities are associated to each market orientation dimension (Li \& Calantone , 1998). For example, the first component called market intelligence generation is associated with the process of continuous monitoring and gathering of information on both the current and future needs of customers, and analysis of the exogenous factors that may influence those needs, the effect of government regulation, competition, technology and other environmental forces. The second component is associated with the dissemination of market intelligence, which is the vertical and horizontal flow and sharing of information gathered at the early stages of an organization. The last component of market orientation is called responsiveness and incorporates actions involving the design and selection of products and services, the production, distribution and promotion of the product.

\subsection{Performance}

Organizational performance is considered as a dependent variable in this study, one of the most important structures in management research and undoubtedly the most important measure of success in business enterprises. Performance in terminology is explained as the state or quality of work; thus, organizational performance is an overall organizational structure referring on the way organizations operate (Neely et al., 2002). However, wrongly, many believe that it is associated with the profitability of the organization, while, in reality it is evaluated and measured based on company's managerial thinking, organizational philosophy, mission, environmental conditions and countless others. Therefore, we must apply a number of indicators and criteria for this purpose. Relevant studies have determined different factors in this matter, while, few have categorized a number of related components in particular groups. For instance, Pelhum (1997) presented three following categories:

1. Organizational Effectiveness: Including product quality, new product success and customer retention rate.

2. Growth/share: Including the level of sales, sales growth and market share.

3. Profitability: Including special rate of return, return on equity and gross profit margin.

Neely et al. (2002) defined performance as the process of indication the quality, effectiveness and efficacy of previous activities. According to this definition, performance is categorized into two components: (1) efficiency, which explains how firms exert resource in services and manufacturing products; or the relationship between the actual and desired inputs for given outputs; and (2) effectiveness, which determines the extent in which an organization has achieved its goals. These objectives can be generally explained in terms of appropriate standards, the extent of compliance with customer's requirements, and features such as frequency and quality in terms of the extent of fulfillment of the required standards. 


\subsection{Literature Review}

Some studies accomplished among Iranian firms and indicated that marketing research significantly could impact market orientation and performance. Furthermore, market orientation had a significant effect on performance, while mediating role of marketing orientation in the relationship between market research and performance was met with skepticism.

In a survey by Doaei and Bakhtiari (2007) it was stated that market orientation had a positive impact on the performance of some Iranian companies and claimed that as organizational activities get oriented toward market and customers, it yields improved organizational performance. Moreover, some other researchers provided a model to determine the impact of market orientation on business performance in the chemical industry and concluded that the current competitive business environment in under effect of the integrity of the market orientation and marketing capabilities. Other scholars confirmed a positive relationship between organizational learning and performance (e.g. Deshpandé et al., 2003; Rodriguez Cano et al., 2004; Khandekar \& Sharma, 2006; Lin \& Kuo, 2007), who came to the conclusion that the learning mediates these relationships.

\section{Conceptual model and hypotheses}

Fig. 1 demonstrates the proposed conceptual model of this survey.

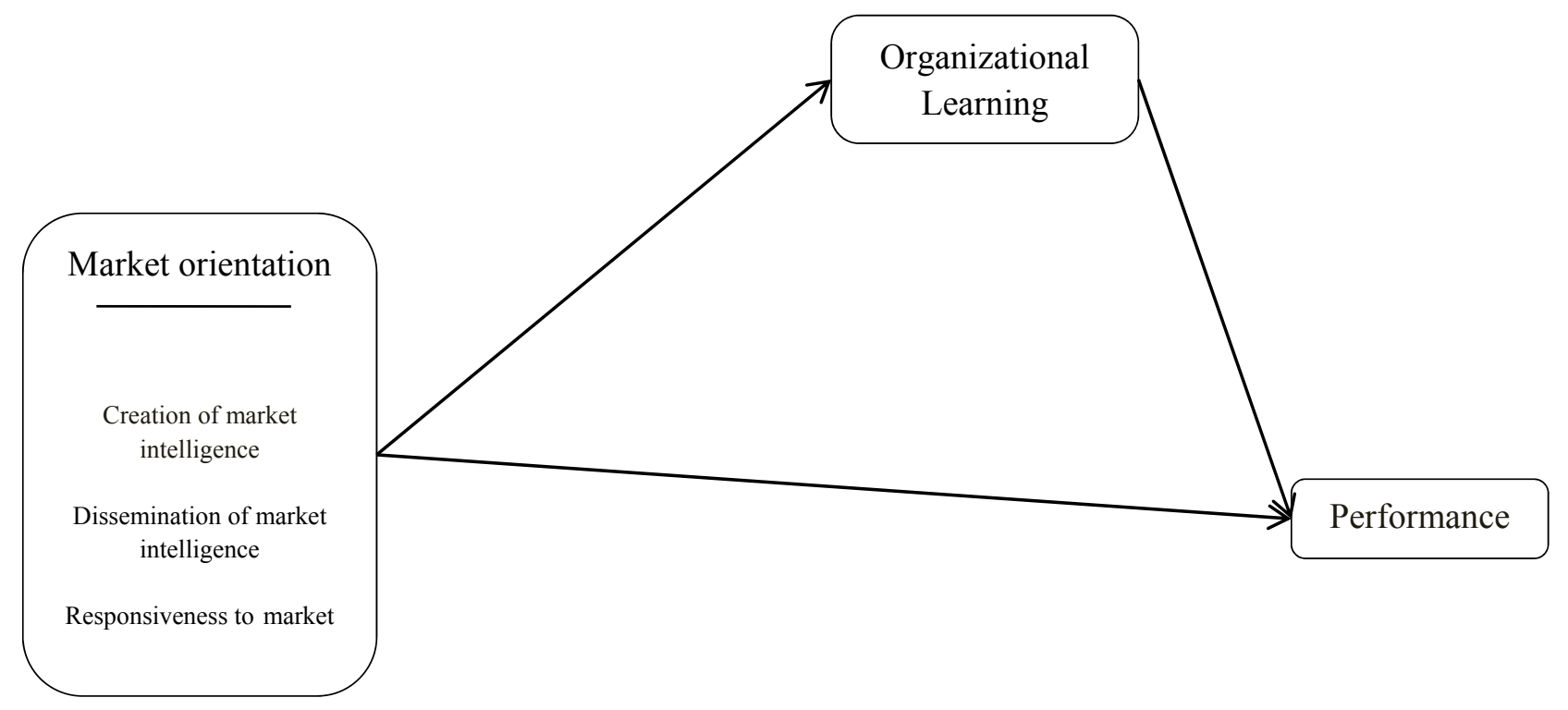

Fig. 1. Conceptual model of research

$\mathrm{H}_{1}$ : Market orientation has a significant and positive impact on the overall performance of the organization.

$\mathrm{H}_{2}$ : Market orientation has a significant and positive impact on organizational learning.

$\mathrm{H}_{3}$ : Organizational Learning has a significant and positive impact on the overall performance of the organization.

$\mathrm{H}_{4}$ : Organizational Learning mediates the relationship between market orientation and organizational learning.

\section{Methodology}

This study is categorized as an applied, descriptive and correlational survey aiming to state variables and their inter-relationships. The research variables are: market orientation as the independent 
variable, organizational learning as the mediator and organizational performance as the dependent variable.

\subsection{Data Collection}

One of the most common methods implemented to gather a survey data is questionnaire. Regarding to this, as it is clear how to measure study variables and according to the level of accuracy required in data collection and other expenses during the period of the survey, quantitative questionnaire considered a best practice for data collection. The study questionnaire using Likert's five-scaled items consists of 29 items, 21 with a range of "totally disagree" to "strongly agree", and eight scales based on a spectrum from "decreasing trend" to "increase trend". 29 items are to be divided into 3 parts: (1) market orientation with 9 items derived from MARKOR Scale (Kohli \& Jaworski, 1993) (2) organizational learning, with 12 items extracted from López et al. (2004) and (3) performance, with 8 items drawn from Quinn and Rohrbaugh (1983). The first part (market orientation) consists of three units of intelligence generation, intelligence dissemination and responsiveness to market; the second part (organizational learning) has four parts: knowledge acquisition, information distribution, information interpretation, and organization memory; and the third part (performance) also have three dimensional models: open-internal model, rational model and human relationships model.

\subsection{Research Population and Sample}

The study's population consists of all the employees in the Central Office of Ferdowsi University of Mashhad, a total number of 330. Random sampling is used to gather required data since each individual has equal probability of being selected and also the population is homogeneous. Among the population, 170 self-administered questionnaires were distributed and gathered.

\subsection{Scale's Validity and Reliability}

Questionnaire items' validity was assessed using exploratory factor analysis. As you can see in Table 1 , for three variables of market orientation, organizational learning and performance, analysis results are demonstrated.

\section{Table 1}

Results of Exploratory Factor Analysis

\begin{tabular}{|c|c|c|c|}
\hline Creation of market intelligence & $\begin{array}{c}\text { IG1 } \\
0.633\end{array}$ & $\begin{array}{c}\mathrm{IG} 2 \\
.6960\end{array}$ & $\begin{array}{l}\text { IG3 } \\
.5580\end{array}$ \\
\hline Dissemination of market intelligence & $\begin{array}{l}\text { ID1 } \\
.5950\end{array}$ & $\begin{array}{l}\text { ID2 } \\
.4640\end{array}$ & $\begin{array}{l}\text { ID3 } \\
.6200\end{array}$ \\
\hline Responsiveness to market & $\begin{array}{l}\text { RE1 } \\
.5130\end{array}$ & $\begin{array}{l}\text { RE2 } \\
.6890\end{array}$ & $\begin{array}{l}\text { RE3 } \\
.5960\end{array}$ \\
\hline Knowledge acquisition & $\begin{array}{c}\text { KA1 } \\
0.694\end{array}$ & $\begin{array}{c}\text { KA2 } \\
0.656\end{array}$ & $\begin{array}{c}\text { KA3 } \\
0.625\end{array}$ \\
\hline Information distribution & $\begin{array}{l}\text { IND1 } \\
0.525\end{array}$ & $\begin{array}{l}\text { IND2 } \\
0.756\end{array}$ & $\begin{array}{l}\text { IND3 } \\
0.591\end{array}$ \\
\hline Information interpretation & $\begin{array}{c}\text { II1 } \\
0.579\end{array}$ & $\begin{array}{c}\text { II2 } \\
0.675\end{array}$ & $\begin{array}{c}\text { II3 } \\
0.673\end{array}$ \\
\hline Organization memory & $\begin{array}{l}\text { OM1 } \\
0.638\end{array}$ & $\begin{array}{l}\text { OM2 } \\
0.682\end{array}$ & $\begin{array}{l}\text { OM3 } \\
.5610\end{array}$ \\
\hline Open-internal model & $\begin{array}{l}\text { OR1 } \\
.6820\end{array}$ & $\begin{array}{l}\text { OR2 } \\
.6380\end{array}$ & $\begin{array}{c}\text { OR3 } \\
0.594\end{array}$ \\
\hline Rational model & $\begin{array}{c}\text { RR1 } \\
0.416\end{array}$ & $\begin{array}{c}\text { RR2 } \\
0.702\end{array}$ & $\begin{array}{c}\text { RR3 } \\
0.655\end{array}$ \\
\hline Human relationships model & $\begin{array}{c}\text { HR1 } \\
0.816\end{array}$ & $\begin{array}{c}\text { HR2 } \\
0.816\end{array}$ & \\
\hline
\end{tabular}


Cronbach's alpha coefficients, as the most common internal consistency test in multifactorial scales, were applied to measure scales' reliability. Table 2 reveals the results. Since the value of all these coefficients for all components are close to or above 0.7 , we can declare that study questionnaire has a reasonable level of reliability.

Table 2

Results of the reliability study

\begin{tabular}{cccccccccc}
\hline \multicolumn{2}{c}{ Organizational Performance } & \multicolumn{4}{c}{ Organizational Learning } & \multicolumn{3}{c}{ Market Orientation } \\
HR & RR & OR & OM & II & IND & KA & RE & ID & IG \\
\hline 0.774 & 0.649 & 0.714 & 0.701 & 0.721 & 0.693 & 0.733 & 0.665 & 0.605 & 0.701 \\
\hline
\end{tabular}

\subsection{Exploratory Data Analysis}

Prior to analyzing the data, exploratory analysis has been fully implemented to ensure study assumptions and conditions met the pre-requisites to run any methods of data analysis on. Considering qualifying results, (Shown in Table 3), parametric statistical tests were employed. Since the aim of any research project is to detect a relationship and identify its power for estimating purposes, this study has utilized correlation test and regression analysis in order to analyze proposed relationships.

\section{Table 3}

Results of Kolmogorov-Smirnov test of normality based on data

\begin{tabular}{cc}
\hline Variable name & Significant \\
\hline OM & 0.226 \\
OL & 0.215 \\
P & 0.346 \\
\hline
\end{tabular}

\section{Data Analysis}

\subsection{Demographic Characteristics of Respondents}

In our survey, $32 \%$ of questionnaire respondents aged 25 to $34,28 \%$ between 35 and 44 , 32\% were 45 to 54 and finally $8 \%$ aged 55 to 64 . Of the respondents, $71 \%$ were male, all known to have at least 2 years of managerial experience up to 28 years. Regarding educational level of total 170 respondents, $19 \%$ had diploma, $7 \%$ associate degrees, $43 \%$ undergraduates, $23 \%$ graduates, and $8 \%$ had a doctorate.

\subsection{Hypotheses Testing}

To determine the relationship between variables, Pearson correlation analysis was employed using SPSS software. Arithmetic means, standard deviations and correlations for are shown in Table 4.

Table 4

Correlation matrix analysis

\begin{tabular}{|c|c|c|c|c|c|c|c|c|c|c|c|c|}
\hline & Mean & Std. dev. & IG & ID & $\mathrm{RE}$ & KA & IND & II & OM & OR & RR & HR \\
\hline IG & 4.0020 & 0.83599 & 1 & & & & & & & & & \\
\hline ID & 4.1980 & 0.74712 & 0.214 & 1 & & & & & & & & \\
\hline $\mathrm{RE}$ & 4.0255 & 0.81165 & 0.216 & 0.238 & 1 & & & & & & & \\
\hline KA & 4.1627 & 0.72545 & 0.231 & 0.277 & 0.479 & 1 & & & & & & \\
\hline IND & 3.8961 & 0.81508 & 0.239 & 0.277 & 0.312 & 0.280 & 1 & & & & & \\
\hline II & 3.9118 & 0.87971 & 0.216 & 0.247 & 0.276 & 0.230 & 0.202 & 1 & & & & \\
\hline $\mathrm{OM}$ & 4.0196 & 0.80817 & 0.273 & 0.239 & 0.239 & 0.287 & 0.258 & .2070 & 1 & & & \\
\hline OR & 3.9804 & 0.82507 & 0.232 & 0.269 & 0.274 & 0.274 & 0.284 & 0.271 & 0.214 & 1 & & \\
\hline RR & 4.1745 & 0.73264 & .2650 & 0.264 & 0.206 & 0.246 & 0.287 & 0.250 & 0.297 & 0.270 & 1 & \\
\hline HR & 4.2147 & 0.93078 & 0.287 & 0.265 & 0.263 & 0.255 & .2540 & 0.254 & 0.274 & 0.219 & 0.218 & 1 \\
\hline
\end{tabular}


As Table 4 reveals, the results of correlation analysis, the overall relationships between study variables are acceptable; this clearly confirms previous studies. Since this study sought to assess and analyze proposed mathematical relationships, so that it can help to quantify an unknown variable using known ones, we can use the following regression equation for each table to test the relevant hypotheses.

$\mathrm{Y}: \mathrm{a}+\beta_{1} \mathrm{X}_{1}+\beta_{2} \mathrm{X}_{2}+$

$Y$ : dependent variable (performance), a: constant,

$\mathrm{X}_{1}$ : the independent variable (market orientation and its components),

$\mathrm{X}_{2}$ : mediating variable (organizational learning), : randomized confounders.

For regression analysis, first we conducted a general regression assessment of the mediating role of organizational learning in the relationship between performance and market orientation. Then if significant, we evaluate three total regressions of market orientation components along with linear regression equation to examine their significance and mediating role of organizational learning to be specified for each relationship. Furthermore, to answer research questions and to determine the extent of the effect of independent variables on the dependent ones and also comparing the effects of these variables, we utilize standardized $\beta$ coefficients. At that scale, the possibility of comparing same variables' parameter estimates is provided.

Table 5

The Investigation of Mediating Role of OL in Relationship between MO on $\mathrm{P}$

\begin{tabular}{cccccccc}
\hline Variables & $\mathrm{b}$ & $\mathrm{S} . \mathrm{E}$ & $\beta$ & t-value & $\begin{array}{c}\text { Significant } \\
\text { level }\end{array}$ & Hypotheses & Results \\
\hline (constant) & 3.219 & 0.334 & & 9.644 & 0.000 & & \\
MO & 0.222 & 0.081 & 0.206 & 2.729 & 0.007 & $\mathrm{H}_{1}$ & Confirmed \\
OL & 0.140 & 0.085 & 0.339 & 3.201 & 0.014 & $\mathrm{H}_{4}$ & Confirmed \\
$\mathrm{R}^{2}: 0.650$ & & & & & \\
$\mathrm{Y}: 3.219+0.222 \mathrm{MO}+0.140 \mathrm{OL}+$ & & & & & & \\
\hline${ }^{*} \mathrm{P} \leq 0.05$
\end{tabular}

As can be seen in Table 5, 65\% of changes yield because of changes in market orientation. Thus, considering significance level $(\mathrm{P} \leq 0.05)$, hypotheses $\mathrm{H}_{1}$ and $\mathrm{H}_{4}$ are confirmed. For every unit change in market orientation, a 0.206 unit change is caused in performance. In case of learning organization playing a mediating role, a unit change in market orientation will cause a 0.339 unit change in performance. This rate of change supports the relationship between market orientation and performance through organizational learning acting as mediator.

Table 6

The Investigation of Role MO on OL

\begin{tabular}{|c|c|c|c|c|c|c|c|}
\hline Variables & $\mathrm{b}$ & S.E & $\beta$ & t-value & Significant level* & Hypotheses & Results \\
\hline (constant) & 2.228 & 0.302 & & 7.366 & 0.00 & & \\
\hline $\mathrm{MO}$ & 0.424 & 0.74 & 0.414 & 5.891 & 0.00 & $\mathrm{H}_{2}$ & Confirmed \\
\hline $\mathrm{R}^{2}: 0.171$ & & & & & & & \\
\hline
\end{tabular}

Table 7

The Investigation of Role OL on P

\begin{tabular}{cccccccc}
\hline Variables & $\mathrm{b}$ & $\mathrm{S} . \mathrm{E}$ & $\beta$ & t-value & Significant level* & Hypotheses & Results \\
\hline (constant) & 3.901 & 0.319 & & 8.264 & 0.00 & & \\
OL & 0.154 & 0.79 & 0.142 & 4.495 & 0.02 & $\mathrm{H}_{3}$ & Confirmed \\
\hline $\mathrm{R}^{2}: 0.132$ & & & & & & \\
\hline$* \mathrm{P} \leq 0.05$ & & & & & &
\end{tabular}


As can be seen in Table 8, market orientation positively affects organizational learning and organizational learning does performance as well. Then we need to check whether including organizational learning as a mediating variable ameliorates measures of relationship on performance. This convinces us to study the market's three essentials: intelligence generation, intelligence dissemination and responsiveness.

Table 8

The Investigation of Mediating Role of OL in Affecting factors IG ،ID ،RE on P

\begin{tabular}{|c|c|c|c|c|c|c|c|}
\hline \multicolumn{8}{|c|}{ The Investigation of Mediating Role of OL in Affecting IG on P } \\
\hline Variables & $\mathrm{b}$ & S.E & $\beta$ & t-value & $\begin{array}{c}\text { Significant } \\
\text { level* }\end{array}$ & Hypotheses & Results \\
\hline (constant) & 3.745 & 0.188 & & 19.946 & 0.00 & & \\
\hline IG & 0.095 & 0.046 & 0.157 & 2.058 & 0.041 & $\mathrm{H}_{1 \mathrm{a}}$ & Confirmed \\
\hline $\mathrm{OL}$ & 0.056 & 0.078 & 0.254 & 3.207 & 0.030 & $\mathrm{H}_{4 \mathrm{a}}$ & Confirmed \\
\hline \multicolumn{8}{|l|}{$\mathrm{R}^{2}: 0.437$} \\
\hline \multicolumn{8}{|c|}{$\mathrm{Y}: 3.745+0.095 \mathrm{IG}+0.056 \mathrm{OL}+$} \\
\hline \multicolumn{8}{|c|}{ The Investigation of Mediating Role of OL in Affecting ID on P } \\
\hline Variables & $\mathrm{b}$ & S.E & $\beta$ & t-value & $\begin{array}{l}\text { Significant } \\
\text { level* }\end{array}$ & Hypotheses & Results \\
\hline (constant) & 3.679 & 0.219 & & 16.789 & 0.00 & & \\
\hline ID & 0.106 & 0.051 & 0.157 & 2.059 & 0.041 & $\mathrm{H}_{1 \mathrm{~b}}$ & Confirmed \\
\hline $\mathrm{OL}$ & 0.021 & 0.080 & 0.220 & 2.940 & 0.029 & $\mathrm{H}_{4 \mathrm{~b}}$ & Confirmed \\
\hline \multicolumn{8}{|c|}{$\begin{array}{l}\mathrm{R}^{2}: 0.396 \\
\mathrm{Y}: 3.679+0.106 \mathrm{ID}+0.021 \mathrm{OL}+ \\
\text { The Investigation of Mediating Role of OL in Affecting RE on P }\end{array}$} \\
\hline Variables & $\mathrm{b}$ & S.E & $\beta$ & t-value & $\begin{array}{c}\text { Significant } \\
\text { level* }\end{array}$ & Hypotheses & Results \\
\hline (constant) & 3.998 & 0.196 & & 20.352 & 0.00 & & \\
\hline RE & 0.031 & 0.048 & 0.050 & 0.651 & 0.516 & $\mathrm{H}_{1 \mathrm{c}}$ & Rejected \\
\hline $\mathrm{OL}$ & 0.043 & 0.052 & .070 & 0.671 & 0.276 & $\mathrm{H}_{4 \mathrm{c}}$ & Rejected \\
\hline
\end{tabular}

$\mathrm{R}^{2}: 0.116$

$* \mathrm{P} \leq 0.05$

According to results presented in Table 8 , and studies conducted on the variables, we can concluded that research data support the hypotheses $\mathrm{H}_{2 b}, \mathrm{H}_{1 b}, \mathrm{H}_{2 a}, \mathrm{H}_{1 \mathrm{a}}$ due to significant level of $\mathrm{b}$ and $\mathrm{R}$. However, the mediating role of the organizational learning in the relationship between responsiveness and performance, due to a insignificance level of $\mathrm{P}, \mathrm{H}_{2 \mathrm{c}}$ and $\mathrm{H}_{1 \mathrm{c}}$ are rejected.

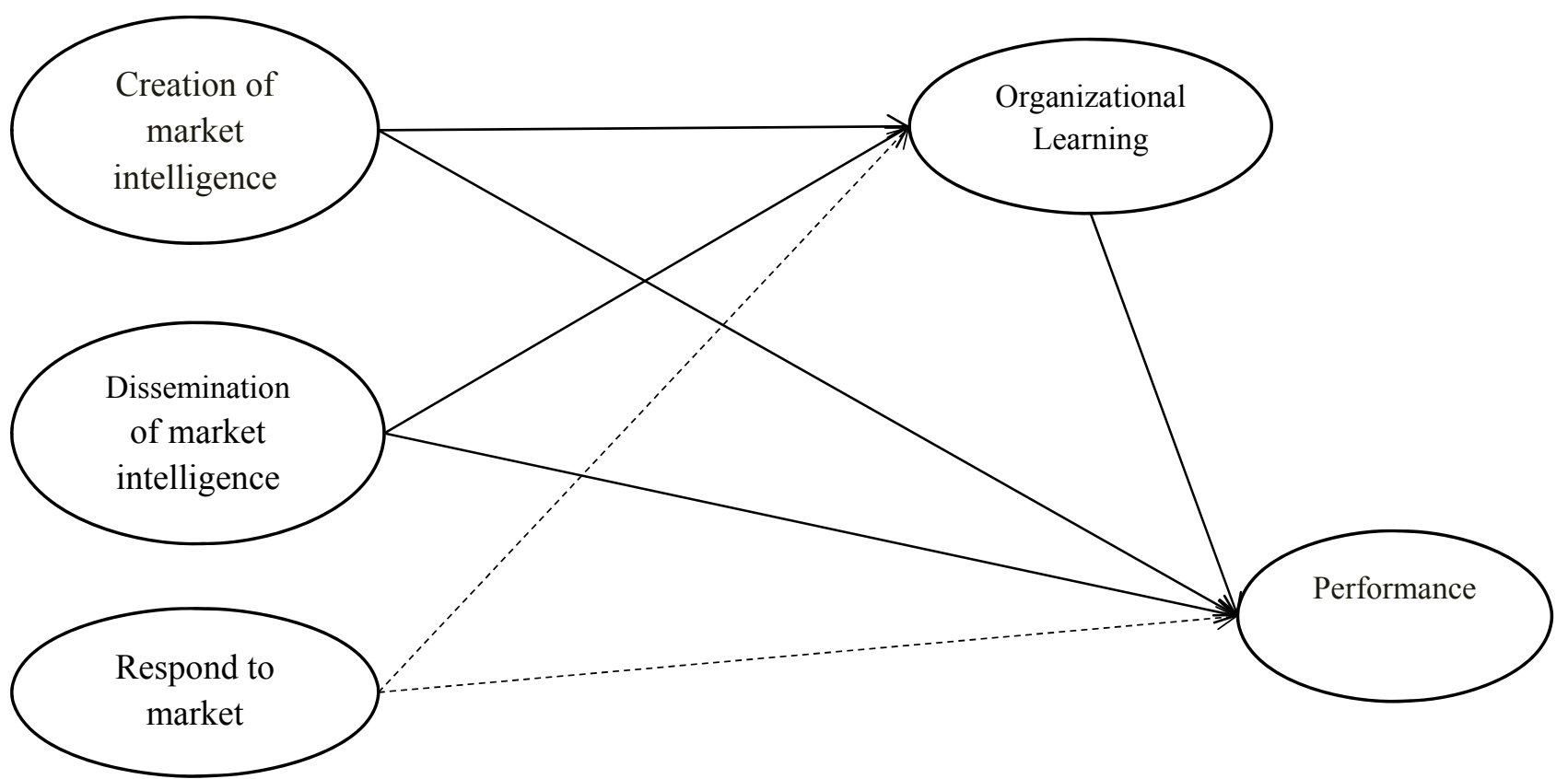

Significant relationship 


\section{Discussion, Conclusions and Recommendations}

In the present study, in order to investigate the mediating role of organizational learning in the relationship between market orientation and organizational performance among employees of Ferdowsi University of Mashhad's Central Office, several statistical techniques were employed. Firstly, Pearson correlation analysis demonstrated that all assumed relationships, except the mediating role, are reasonably confirmed. Then, research hypotheses were tested using multiple regression, as the mediating role of learning in the relationship between intelligence generation and intelligence dissemination with performance were approved, while data did not the same for responsiveness. Based on the values obtained for the $\beta$, the impact of intelligence generation and intelligence dissemination were equal $(\beta=0.157)$.

The results are quite clear about the fact that responsiveness's impact on performance, even with organizational learning acting as a mediator, was insignificant. The reason behind this can be found in organization's responding strategy, as many of employees are formally tenured and in the inconsistency between organization's budget and employees' responsiveness. This emphasizes the reason why investing on employees to respond to environment and to enhance the performance is of no doubt. Students should be considered like customers so that customer and customer relationship management (CRM) can be defined. Finally, results obtained suggest that future studies should focus more on responsiveness. Considering the study context was a governmental institution, evaluating private contexts to overcome flaws are highly recommended.

\section{References}

Agarwal, S., Erramilli, M. K., \& Dev, C. S. (2003). Market orientation and performance in service firms: role of innovation. Journal of services marketing,17(1), 68-82.

Argyris, C., \& Schön, D. A. (1997). Organizational learning: a theory of action perspective. Reis, (77/78), 345-348.

Atwood, M. A., Mora, J. W., \& Kaplan, A. W. (2010). Learning to lead: evaluating leadership and organizational learning. Leadership \& Organization Development Journal, 31(7), 576-595.

Akgün, A. E., Lynn, G. S., \& Byrne, J. C. (2003). Organizational learning: a socio-cognitive framework. Human relations, 56(7), 839-868.

Barney, J. B. (1986). Organizational culture: can it be a source of sustained competitive advantage?. Academy of management review, 656-665.

Cadogan, J. W., \& Diamantopoulos, A. (1995). Narver and Slater, Kohli and Jaworski and the market orientation construct: integration and internationalization. Journal of Strategic Marketing, 3(1), 41-60.

Calantone, R. J., Cavusgil, S. T., \& Zhao, Y. (2002). Learning orientation, firm innovation capability, and firm performance. Industrial marketing management,31(6), 515-524.

Daft, R. L., \& Weick, K. E. (1984). Toward a model of organizations as interpretation systems. Academy of management review, 284-295.

Deshpandé, R., Farley, J. U., \& Webster Jr, F. E. (1993). Corporate culture, customer orientation, and innovativeness in Japanese firms: a quadrad analysis. The journal of Marketing, 23-37.

Doaei, H., \& Bakhtiari, A. (2007). The effect of Market Orientation On Business Perfromance: In auto-part maker firms of Mashhad-Iran. Iranian Journal of Trade Studies.

Dobni, C. B. (2008). Measuring innovation culture in organizations: The development of a generalized innovation culture construct using exploratory factor analysis. European Journal of Innovation Management, 11(4), 539-559.

Hoe, S. L., \& McShane, S. (2010). Structural and informal knowledge acquisition and dissemination in organizational learning: An exploratory analysis. Learning Organization, 17(4), 364-386.

Jaworski, B. J., \& Kohli, A. K. (1993). Market orientation: antecedents and consequences. The Journal of marketing, 53-70. 
Jiménez-Jimenez, D., Valle, R. S., \& Hernandez-Espallardo, M. (2008). Fostering innovation: the role of market orientation and organizational learning. European Journal of Innovation Management, 11(3), 389-412.

Kim, D. H. (1993). A framework and methodology for linking individual and organizational learning: Applications in TQM and product development (Doctoral dissertation, Massachusetts Institute of Technology).

Kirca, A. H., Jayachandran, S., \& Bearden, W. O. (2005). Market orientation: a meta-analytic review and assessment of its antecedents and impact on performance. Journal of marketing, 69(2), 24-41.

Kolb, D. A. (1984). Experiential learning: Experience as the source of learning and development (Vol. 1). Englewood Cliffs, NJ: Prentice-Hall.

Kohli, A. K., \& Jaworski, B. J. (1990). Market orientation: the construct, research propositions, and managerial implications. The Journal of Marketing, 1-18.

Kotlar, P. (2000). Marketing Management. Millennium Edition.

Li, T., \& Calantone, R. J. (1998). The impact of market knowledge competence on new product advantage: conceptualization and empirical examination. The Journal of Marketing, 13-29.

Lings, I. N. (2004). Internal market orientation: construct and consequences. Journal of Business Research, 57(4), 405-413.

Lopez, S. P., Peón, J. M. M., \& Ordás, C. J. V. (2004). Managing knowledge: the link between culture and organizational learning. Journal of knowledge management, 8(6), 93-104.

Neely, A. D., Adams, C., \& Kennerley, M. (2002). The performance prism: The scorecard for measuring and managing business success. London: Prentice Hall Financial Times.

Nevis, E. C., DiBella, A. J., \& Gould, J. M. (1995). Understanding organizations as learning systems. Sloan management review, 36(2), 73-85.

Pelham, A. M. (1997). Market orientation and performance: the moderating effects of product and customer differentiation. Journal of Business \& Industrial Marketing, 12(5), 276-296.

Probst, G. J., \& Büchel, B. S. (1997). Organizational learning: The competitive advantage of the future (pp. 15-31). London: Prentice Hall.

Quinn, R. E., \& Rohrbaugh, J. (1983). A spatial model of effectiveness criteria: towards a competing values approach to organizational analysis. Management science, 29(3), 363-377.

Rodriguez Cano, C., Carrillat, F. A., \& Jaramillo, F. (2004). A meta-analysis of the relationship between market orientation and business performance: evidence from five continents. International Journal of research in Marketing,21(2), 179-200.

Simon, H. A. (1991). Bounded rationality and organizational learning.Organization science, 2(1), $125-134$ 